\section{静的面内圧縮力を受ける鋼製下 地吊り天井の力学特性}

\title{
MECHANICAL PROPERTIES OF STEEL FURRING SUSPENDED CEILING SYSTEM UNDER STATIC IN-PLANE COMPRESSION
}

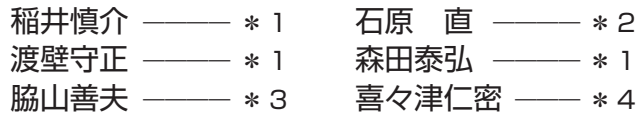

キーワード :

鋼製下地吊り天井，静的実験，天井懐，開口，大規模実験

Keywords:

Steel furring suspended ceiling system, Static tests, Suspended length of ceiling, Opening, Large scale tests

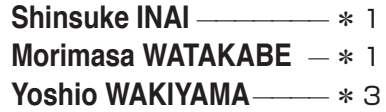

Tadashi ISHIHARA — $* 2$
Yasuhiro MORITA — $* 1$
Hitomitsu KIKITSU $-* 4$

In recent years, suspended ceilings were often damaged by earthquakes. Investigations on seismic capacity of ceilings have been conducted by some researchers. The new standard for ceilings against earthquakes requires a relatively large clearance around those to prevent collision with surrounding walls. On the other hand, there are still the needs for ceilings without clearance because of workability or room's uses. In this paper, mechanical properties of steel furring suspended ceiling system for in-plane compression are clarified by static compression tests, using small and large scale specimen. Those properties are essential to evaluate the seismic capacity of ceilings without clearance.

\section{1. はじめに}

近年、天井の脱落被害が注目され、その耐震対策の検討が進めら れている。2014 年 4 月 1 日からは天井告示 ${ }^{1)}$ (平成 25 年国土交通 省告示第 771 号等）が施行され、特定天井を対象とした天井の耐震 対策が示された。告示では地震時の水平力を斜め部材で負担し、天 井が周囲の壁等と衝突しないよう所定のクリアランスを設けること が前提となっている。一方で、建物用途（音響に配慮する必要があ るホールや、気密性の求められるクリーンルーム等）や施工性等を 考えた場合、周囲にクリアランス設けない天井 ${ }^{2) ~ 3)}$ に対するニーズ も多い。クリアランスを設けない天井では、構造躯体の層間変形へ の追随を考慮して斜め部材は設置しない。地震時の水平力は天井の 面内圧縮力として、周囲の壁等に伝達される必要があるため、天井 の耐震対策を検討寸る上では、その剛性や耐力を把握しておくこと が重要となる。本稿では、静的面内圧縮実験により、天井の面内剛 性、耐力、および破壊性状について検討した結果を示す。

\section{2. 実験概要}

\section{1 試験体}

図1～図 2、表 1 に試験体概要と天井構成材の仕様をそれぞれ示す。 また、写真 1 に実験状況を示寸。試験体は JIS A6517 の鋼製下地吊 り天井とし、斜め部材は設置しなかった。平面寸法は $3.85 \mathrm{~m} \times 1.82 \mathrm{~m}$

$\left(\right.$ 約 $7 \mathrm{~m}^{2}$ ) の小規模試験体（図 1、写真 $1(\mathrm{a})$ ) と、 $16.5 \mathrm{~m} \times 4.8 \mathrm{~m}$ （約 $80 \mathrm{~m}^{2}$ ) の大規模試験体（図 2、写真 1 (b)）の 2 種類とした。前者は 各種パラメータの影響を確認するため、後者は天井規模が力学特性

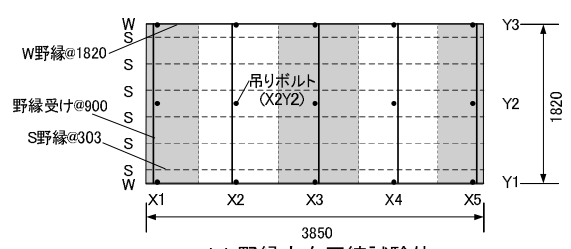

(a) 野縁方向圧縮試験体 Sa

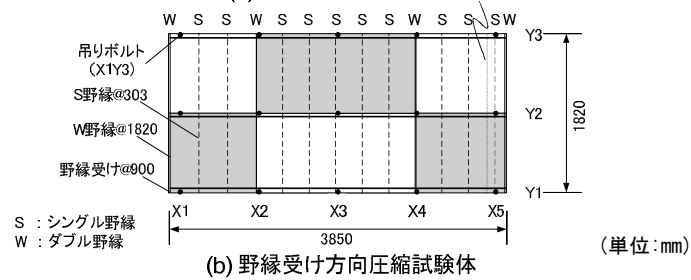

図 1 試験体概要（小規模試験体）

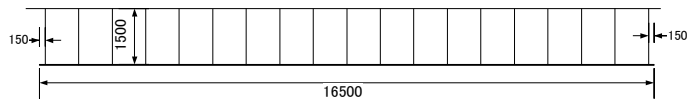

(a)立面図

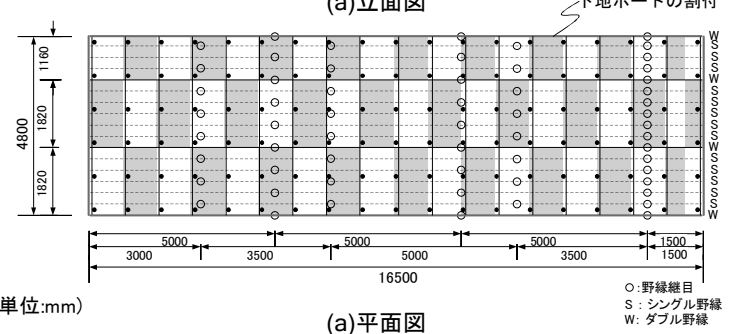

図 2 試験体概要 (大規模試験体)

本稿は参考文献 4) で発表した内容を基に加筆・修正してまとめたものである。

戸田建設(株)開発センター

(テ 300-2622 つくば市要 315)

独建築研究所建築生産研究グループ 主任研究員・博士（工学）

3 国土交通省国土技術政策総合研究所建築研究部 主任研究官・博士（工学）

4 独建築研究所構造研究グループ 主任研究員・博士（環境学）

Toda Corporation, Technical Research Institute

*2 Senior Research Engineer, Dept. of Production Eng., Building Research Institute Dr. Eng.

Senior Researcher, Building Dept., National Institute for Land and Infrastructure Management, Dr. Eng.

Senior Research Engineer, Dept. of Structural Eng., Building Research Institute, Ph. D. 
に及ぼす影響を確認することを目的とした。天井懐は $1.5 \mathrm{~m}$ と $2.7 \mathrm{~m}$ 、 枚数は 1 枚張りと 2 枚張りとした。吊元は、吊りボルトを上部フレ ームにナットで締め付けて固定した。圧縮力をボードのみに作用さ せるため、下地材は天井端より $20 \mathrm{~mm}$ 内側までとした (写真 1 (a))。 野縁とボードはビス留めとし、大規模試験体には耐風圧クリップを 用いた (写真 1 (b) ) 。表 2 に試験体一覧を示す。実験パラメータは、

下地材方向の影響を確認する圧縮方向、ボード枚数、下地材・クリ ップの規格、試験体サイズ、ボード割付（図 4 参照）、天井懐、水平 補剛材（写真 2 に接合部詳細を示す）の有無、および開口の有無・ 開ロサイズ (図 5 参照) 等とした。表中の損傷荷重 $P_{\mathrm{d}}$ は、載荷後初 めに荷重低下が観察されるまでの極大值を試験体幅で除した值と定 義している。また、右欄の $\mathrm{Pd} / \mathrm{w}$ は、損傷荷重を単位面積重量で除 して算出した值であり、天井の耐力を長さの単位で示したものであ る。これは、設計震度 1 (天井自重分に相当、後述 3.4 参照) のと き実現できる長さを示しており、この值により設計震度に応じた天

表 1 天井構成材の仕様

\begin{tabular}{|c|c|c|}
\hline \multirow{2}{*}{ 項目 } & \multicolumn{2}{|c|}{ 仕様 } \\
\hline & 小規模試験体 & 大規模試験体 \\
\hline 試験体長さ & $3,850 \mathrm{~mm}$ & $16,500 \mathrm{~mm}$ \\
\hline 試験体幅 & $1,820 \mathrm{~mm}$ & $4,800 \mathrm{~mm}$ \\
\hline 吊りボルト & $3 / 8 @ 900 \mathrm{~mm}$ & $3 / 8 @ 900 \mathrm{~mm}$ \\
\hline 天井懐 & $1,500 \mathrm{~mm} / 2,700 \mathrm{~mm}$ & $1,500 \mathrm{~mm}$ \\
\hline 野縁受け & CC-19@900mm & CC-19@900mm \\
\hline 水平補剛材 & CC-19@1,800mm (天井懐2,700mm) & - \\
\hline ハンガー & JISハンガー & JISハンガー \\
\hline シングル野縁 & CS-19@303mm & CS-19@303mm \\
\hline ダブル野縁 & CW-19@1,820mm & CW-19@1,820mm \\
\hline シングルクリップ & CS-19/耐風圧クリップ@303mm & 耐風圧クリップ@303mm \\
\hline ダブルクリップ & cW-19/耐風压リップ@1,820mm & 耐風圧クリップ@1,820mm \\
\hline 面材 & せっこうボード9. $5 \mathrm{~mm}$ 1枚張り/2枚張り & せっこうボード9.5mm 2枚張り \\
\hline
\end{tabular}

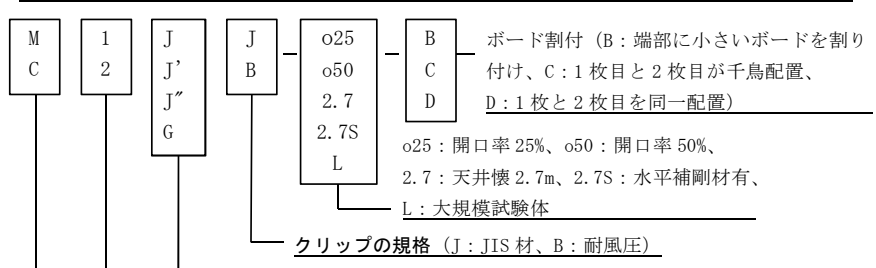

下地材の規格 (J：JIS 材、J'：JIS 材 加力梁と接触、

J" : JIS 材下地配置変更 図 1 (b) に示寸 $S a 、 G ：$ 一般材)

— —圧縮方向 (M:野縁方向、C：野縁受け方向）体、天井㯖 1.5m、開口なし、ボード割付A 図 3 試験体記号
井長さをおおよそ把握することが可能となる。図 3 に試験体記号の 詳細を、写真 3 に下地材の規格の違いを示す。J’は、が端部をボ ードのみ接触（写真 $3(\mathrm{a}-1)$ ) させているのに対し、一部の下地材が 加力梁と接触している (写真 $3(\mathrm{a}-2))$ 。 J”は、Jが端部下地間隔が狭 い(写真 $3(b-1))$ のに対し、端部下地間隔をほぼ均等 (写真 $3(b-2))$ としている。
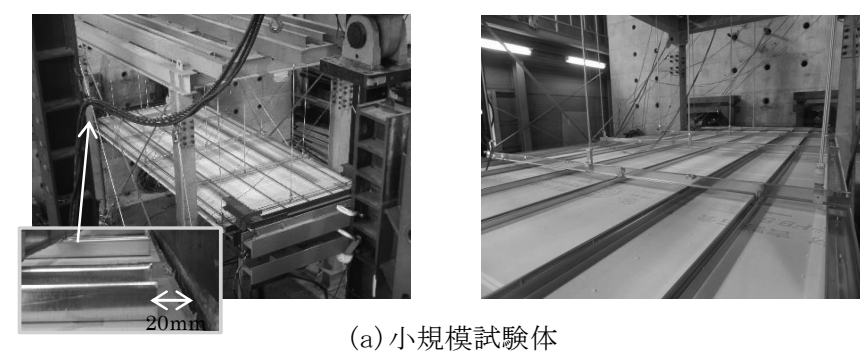

(a) 小規模試験体
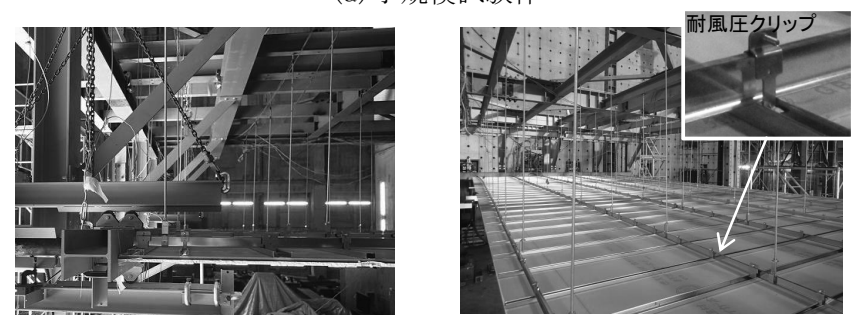

(b) 大規模試験体

写真 1 実験状況

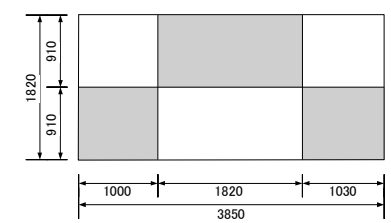

(a) ボード割付 A

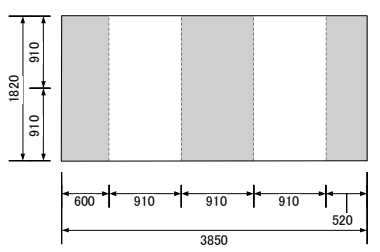

(c) ボード割付C（仕上割付）

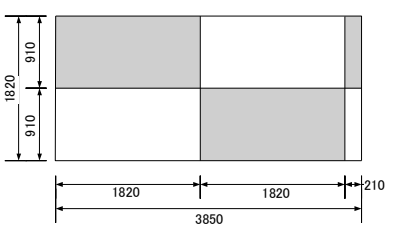

(b) ボード割付 $B$

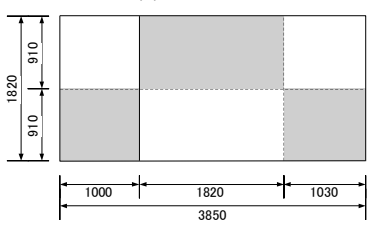

(d) ボード割付D（仕上割付）
図 4 ボード割付

表 2 試験体一覧

\begin{tabular}{|c|c|c|c|c|c|c|c|c|c|c|c|c|c|c|}
\hline No & 試験体記号 & 圧縮方向 & $\begin{array}{l}\text { 平面寸法 (m) } \\
\text { (圧縮方向 } \times \text { 幅方向) }\end{array}$ & $\begin{array}{c}\text { 天井懐 } \\
(\mathrm{m})\end{array}$ & $\begin{array}{c}\text { ボード } \\
\text { 枚数 }\end{array}$ & $\mid \begin{array}{l}\text { ボード } \\
\text { 割付※1 }\end{array}$ & $\begin{array}{c}\text { ボード } \\
\text { ビス本数※2 } \\
\text { (S野緣, W野縁) } \\
\end{array}$ & $\begin{array}{c}\text { クリップ } \\
\text { 規格 }\end{array}$ & $\begin{array}{l}\text { 水平 } * 3 \\
\text { 補剛材 } \\
\end{array}$ & $\begin{array}{c}\text { 開口率 } \\
(\%)\end{array}$ & $\begin{array}{c}\text { 単位面積 } \\
\text { 重量w } \\
\left(\mathrm{N} / \mathrm{m}^{2}\right) \\
\end{array}$ & $\begin{array}{c}\text { 損傷荷重 } \mathrm{P}_{\mathrm{d}}{ }^{* 4} \\
(\mathrm{kN} / \mathrm{m})\end{array}$ & $\begin{array}{l}\text { 剛性※5 } \\
(\mathrm{kN} / \mathrm{m} / \mathrm{mm})\end{array}$ & $\begin{array}{c}\mathrm{P}_{\mathrm{d}} / \mathrm{w} \\
(\mathrm{m})\end{array}$ \\
\hline 1 & M1JJ & 野縁 & $3.85 \times 1.82$ & 1.5 & 1 & $\mathrm{~A}$ & 5,6 & JIS & - & - & 82.0 & 13.53 & 2.22 & 165 \\
\hline 2 & M1J' J & 野縁 & $3.85 \times 1.82$ & 1.5 & 1 & $\mathrm{~A}$ & 5,6 & JIS & - & - & 82.0 & 11.80 & 2.11 & 144 \\
\hline 3 & C1JJ & 野縁受 & $3.85 \times 1.82$ & 1.5 & 1 & A & 6,6 & JIS & - & - & 81.6 & 16.50 & 2.96 & 202 \\
\hline 4 & C1JJ-B & 野縁受 & $3.85 \times 1.82$ & 1.5 & 1 & B & 6,6 & JIS & - & - & 81.6 & 16.10 & 2.68 & 197 \\
\hline 5 & M2JJ-C & $\begin{array}{l}\text { 野縁 } \\
\end{array}$ & $3.85 \times 1.82$ & 1.5 & 2 & $\mathrm{C} / \mathrm{A}$ & 6,6 & JIS & - & - & 143.3 & 22.70 & 4.12 & 158 \\
\hline 6 & C2JJ-C & 野縁受 & $3.85 \times 1.82$ & 1.5 & 2 & $\mathrm{~A} / \mathrm{C}$ & 6,7 & JIS & - & - & 143.0 & 14.10 & 2.14 & 99 \\
\hline 7 & C2JJ-D & 野縁受 & $3.85 \times 1.82$ & 1.5 & 2 & $\mathrm{~A} / \mathrm{D}$ & 6,7 & JIS & - & - & 143.0 & 22.80 & 2.87 & 159 \\
\hline 8 & M1JJ-2. 7 & 野縁 & $3.85 \times 1.82$ & 2.7 & 1 & A & 6,6 & JIS & - & - & 82.0 & 11.30 & 1.34 & 138 \\
\hline 9 & C1JJ-2. 7 & 野縁受 & $3.85 \times 1.82$ & 2.7 & 1 & A & 6,7 & JIS & - & - & 81.6 & 9.20 & 1. 47 & 113 \\
\hline 10 & C2JJ-2.7-C & 野縁受 & $3.85 \times 1.82$ & 2.7 & 2 & $\mathrm{C} / \mathrm{A}$ & 6,6 & JIS & - & - & 143.0 & 9.10 & 1.60 & 64 \\
\hline 11 & M1JJ-2. 7S & 野縁 & $3.85 \times 1.82$ & 2.7 & 1 & A & 6,6 & JIS & 有 & - & 82.0 & 15.66 & 1.69 & 191 \\
\hline 12 & $\mathrm{C} 1 \mathrm{JJ}-2.7 \mathrm{~S}$ & 野縁受 & $3.85 \times 1.82$ & 2.7 & 1 & A & 6,6 & JIS & 有 & - & 81.6 & 12.20 & 2.09 & 149 \\
\hline 13 & M1 JJ-o50 & 野縁 & $3.85 \times 1.82$ & 1.5 & 1 & A & 5,6 & JIS & - & 50 & 74.9 & 12.81 & 2.09 & 171 \\
\hline 14 & M1 J' J-o50 & 野縁 & $3.85 \times 1.82$ & 1.5 & 1 & A & 6,6 & JIS & - & 50 & 74.9 & 15.44 & 2.05 & 206 \\
\hline 15 & M1GJ-o50 & 野縁 & $3.85 \times 1.82$ & 1.5 & 1 & A & 5,5 & JIS & - & 50 & 74.9 & 8.27 & 1.33 & 110 \\
\hline 16 & $\mathrm{C} 1 \mathrm{JJ}-\mathrm{o} 50$ & 野縁受 & $3.85 \times 1.82$ & 1.5 & 1 & $\mathrm{~A}$ & 5,5 & JIS & - & 50 & 73.3 & 11.43 & 1.98 & 156 \\
\hline 17 & C1JJ-o25 & 野縁受 & $3.85 \times 1.82$ & 1.5 & 1 & A & 5,6 & JIS & - & 25 & 81.5 & 17.99 & 2.49 & 221 \\
\hline 18 & M1 JB & 野縁 & $3.85 \times 1.82$ & 1.5 & 1 & A & 5,5 & 耐風圧 & - & - & 84.7 & 12. 15 & 1.71 & 144 \\
\hline 19 & C1JB & 野縁受 & $3.85 \times 1.82$ & 1.5 & 1 & A & 5,5 & 耐風圧 & - & - & 84.5 & 13.20 & 2.84 & 156 \\
\hline 20 & C1J"B & 野縁受 & $3.85 \times 1.82$ & 1.5 & 1 & A & 5,5 & 耐風圧 & - & - & 84.5 & 24.86 & 2. 31 & 294 \\
\hline 21 & M2JB-L & 野縁 & $16.5 \times 4.8$ & 1.5 & 2 & $\mathrm{C} / \mathrm{A}$ & 5,5 & 耐風圧 & - & - & 141.7 & 17.11 & 0.52 & 121 \\
\hline 22 & C2 JB $-\mathrm{L}$ & 野縁受 & $16.5 \times 4.8$ & 1.5 & 2 & $\mathrm{~A} / \mathrm{C}$ & 5,5 & 耐風圧 & - & - & 141.6 & 19.03 & 0.49 & 134 \\
\hline
\end{tabular}




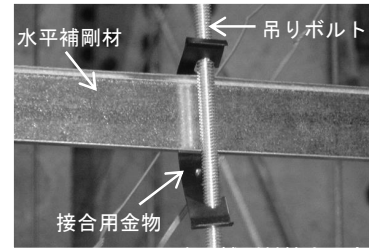

写真 2 水平補剛材接合部

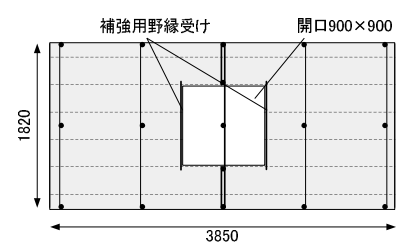

(a) M1JJ-050 (開口率 $50 \%$ ) 補強用野縁 補強用野緑受け 開口 $900 \times 900$

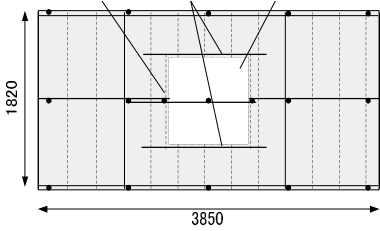

(b) $\mathrm{C} 1 \mathrm{JJ}-050$ (開口率 $50 \%$ )

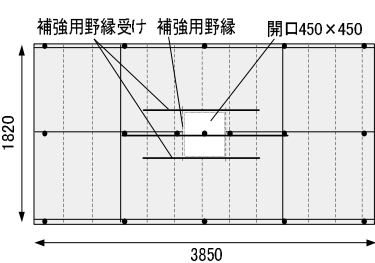

(c) $\mathrm{C} 1 \mathrm{JJ}-\mathrm{O} 25$ (開口率 25\%)

図 5 開口のある試験体

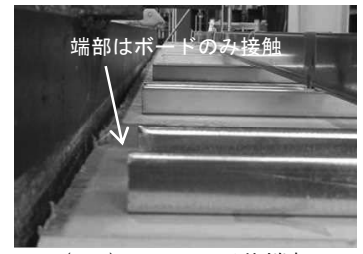

(a-1) M1JJ の天井端部

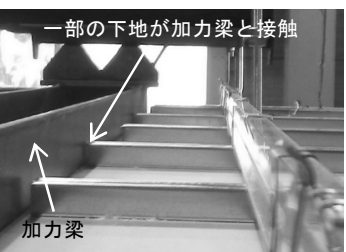

(a-2) M1J'J の天井端部

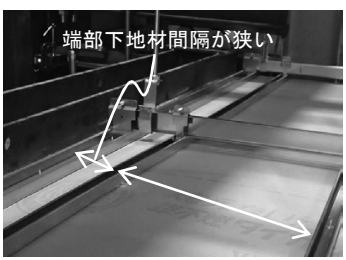

(b-1） C1JB の天井端部

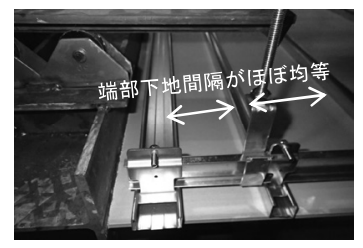

(b-2) $\mathrm{C} 1 \mathrm{~J}^{\prime \prime} \mathrm{B}$ の天井端部

写真 3 下地材の規格

(J’と J”の詳細)

\section{2 実験方法}

小規模試験体を例に実験方法を図 6 に示す。実験は、鉄骨フレー ムから吊り下げた天井の両端を $\mathrm{H}$ 形鋼（加力梁・反力梁）に当て、 反力用ジャッキを固定して、片側から加力用ジャッキにより水平に 載荷することにより行った。大規模試験体も同様である。

\section{3 計測}

計測箇所を小規模試験体を例に図 6 に示す。載荷荷重はロードセ ル、加力梁・反力梁の水平変位はレーザー変位計を用いて計測した。 ロードセルは、加力用ジャッキと加力梁の間に設置した。変位計は、 小規模試験体、大規模試験体とも加力側とその反対側（以下、反力 壁側）の両端 2 箇所（計 4 箇所）に加力方向が正となるように設置 し、両者（加力側、反力壁側とも平均值）の差から天井の変形を算 出した。また、小規模試験体においては吊りボルトの吊元付近にひ ずみゲージを貼り付け（ゲージ貼り付け部のネジ山を円柱状に削っ て加工）、軸ひずみを測定した。

\section{3. 実験結果}

\section{1 荷重と変形の関係}

図 7 に各試験体の単位幅当たり（幅 $1 \mathrm{~m}$ 当たり）の荷重とひずみの 関係を示す。荷重は小規模試験体と大規模試験体の結果を比較する ため、試験体幅で除して単位幅当たりの荷重としている。また、横 軸のひずみは正值で表した圧縮ひずみであり、加力梁の 2 点の平均 変位と反力梁のそれの差を天井長さで除して算出している。

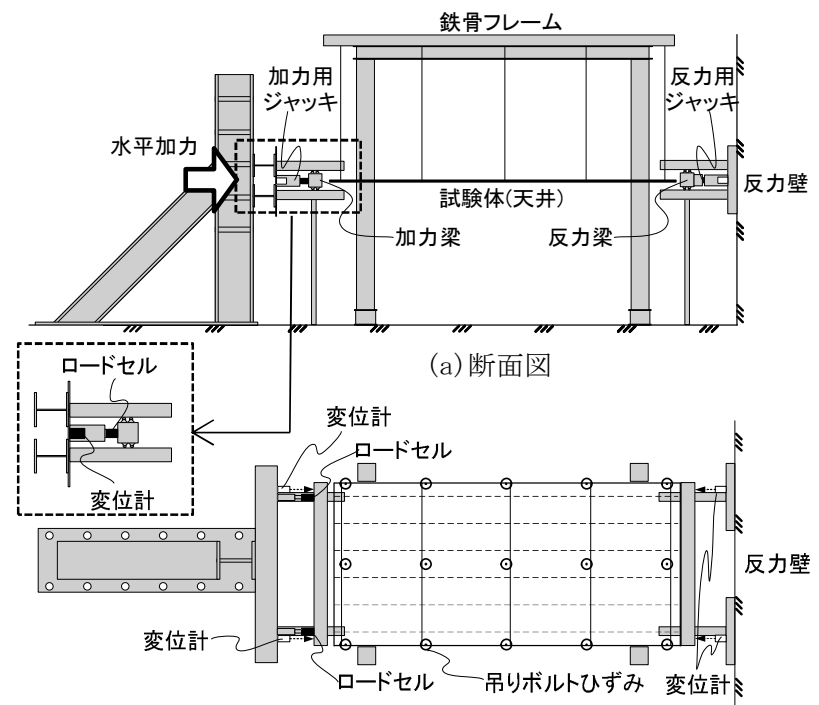

(b) 平面困

図 6 実験方法と計測箇所（小規模試験体）

（1）圧縮方向の違いによる比較

図 7 (a) に圧縮方向の違いによる単位幅当たりの荷重ひずみ関係 の比較を示す。野縁方向圧縮（M1JJ）では損傷荷重は $13.5 \mathrm{kN} / \mathrm{m}$ 、野 縁受け方向圧縮（C1JJ）では $16.5 \mathrm{kN} / \mathrm{m}$ であり、圧縮方向による差が 見られた。一方、ボード 2 枚張りの M $2 J J-C$ と C $2 J J-D$ を比較すると、 両者はほぼ同じ損傷荷重であり圧縮方向による差は見られなかった。 この理由として、ボード 2 枚張りの場合は、ボード枚数が多い分、 ボード自体が損傷荷重に寄与する割合が大きくなるため、相対的に 下地材方向の影響が小さくなっていることが挙げられる。また、野 縁受け方向圧縮では、2 枚張りでボードの割付の違い（C2JJ-C と C2JJ-D)により損傷荷重に大きな差が見られた。野縁方向圧縮では、 損傷荷重後は比較的緩やかに荷重が低下寸るのに対し、野縁受け方 向圧縮では、急激に荷重が低下寸る傾向が見られる。損傷荷重時の ひずみはおよそ $0.0015 \sim 0.003$ であった。天井懐 $2.7 \mathrm{~m}$ の M1JJ-2.7 と C1JJ-2. 7 を比較すると、天井懐 $1.5 \mathrm{~m}$ の場合と違い、野縁方向圧 縮の損傷荷重は、野縁受け方向圧縮の約 1.2 倍であった。野縁受け 方向で損傷荷重が小さいのは、天井懐が大きいほど吊りボルトの変 形や野縁受けの倒れが生じやすいためと考えられる。この結果は、 水平補剛材を入れた M1JJ-2.7S、C1JJ-2.7S の比較でも同じ傾向であ った。

（2）ボード枚数の違いによる比較

図 7 (b)にボード枚数の違いによる単位幅当たりの荷重ひずみ関係 の比較を示す。M2JJ-C は M1JJ の 1.9 倍、また C2JJ-D は C1JJ の 1.4 倍の損傷荷重となり、ボード枚数が多いほど損傷荷重も大きくなる 傾向が見られる。ただし、表 2 に示寸天井長さ (Pd/w) では、枚数 が多くなるほど天井長さは短くなる傾向が見られる。また、剛性 (表 2 脚注参照) は、野縁方向圧縮ではボード 2 枚張りの方が大きい傾 向が見られるが、野縁受け方向ではあまり変わらない。

（３）天井懐の違いによる比較

図 7 (c)に天井懐の違いによる単位幅当たりの荷重ひずみの関係の 比較を示す。M1JJ の損傷荷重は M1JJ-2.7 の約 1.2 倍、C1JJ は C1JJ-2. 7 の約 1.8 倍となった。文献 2) の数值解析で指摘されている ように、天井懐が大きいほど損傷荷重が低下寸る傾向が実験でも確 
かめられた。剛性についても天井懐が大きいほど小さくなる傾向が 見られた。天井懐 $2.7 \mathrm{~m}$ ではボード枚数 1 枚 (C1JJ-2.7) と 2 枚 (C2JJ-2.7-C) で損傷荷重に差はなかった。

(4) 開口の有無・開口率の違いによる比較

図 7 (d) に開口の有無・開口率の違いによる単位幅当たりの荷重ひ ずみ関係の比較を示す。M1JJ とM1JJ-050(図 5(a)) の損傷荷重を比 較すると、ともに約 $13 \mathrm{kN} / \mathrm{m}$ と同程度であり、野縁方向圧縮において は、開口率 50\%としても損傷荷重の低下は見られなかった。また、 野縁に一般材を用いた場合（M1GJ-050）の損傷荷重は、JIS 材を用 いた場合（M1JJ-050）の約 0.6 倍であった。これは、JIS 材が板厚 に規定があるのに対し、一般材では明確な規定がないため、板厚が 薄く断面性能が劣っているためと考えられる。天井面の曲げ実験 4) 5) ではJIS材に比べて一般材では剛性、耐力とも 0.7 倍程度であった。 一方、C1JJ と C1JJ-050(図 5(b)) の損傷荷重を比較すると、C1JJ-050 はC1JJ の約 0.7 倍であり、野縁受け方向圧縮においては、開口によ る損傷荷重の低下が見られた。開口率 25\%の C1JJ-o25（図 5 (c)）の 損傷荷重は C1JJ とほぼ同等であり、この程度の開口率であれば損傷 荷重の低下は見られなかった。なお、今後開口位置の影響に関する
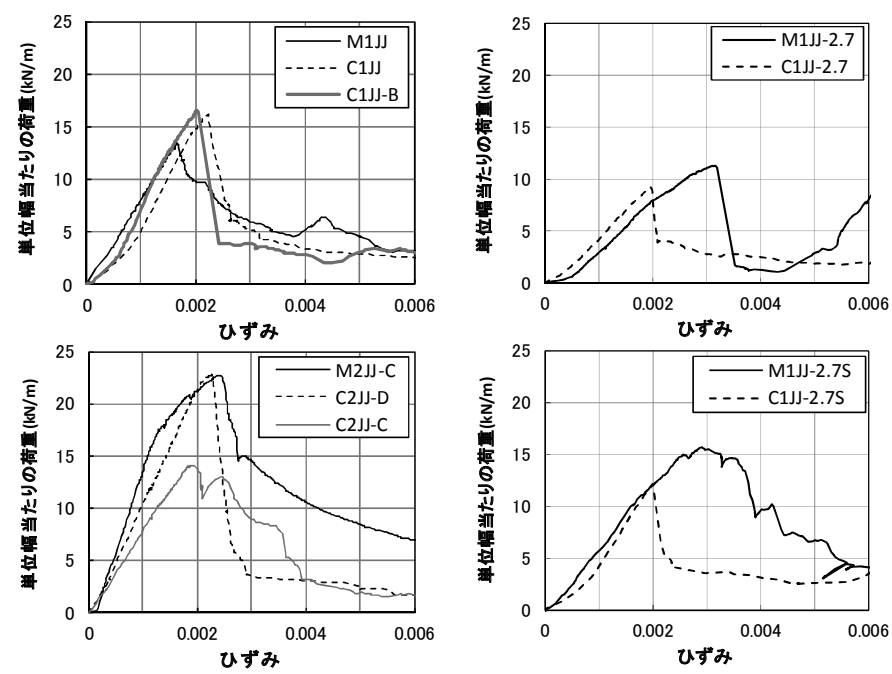

(a) 圧縮方向の違いによる比較
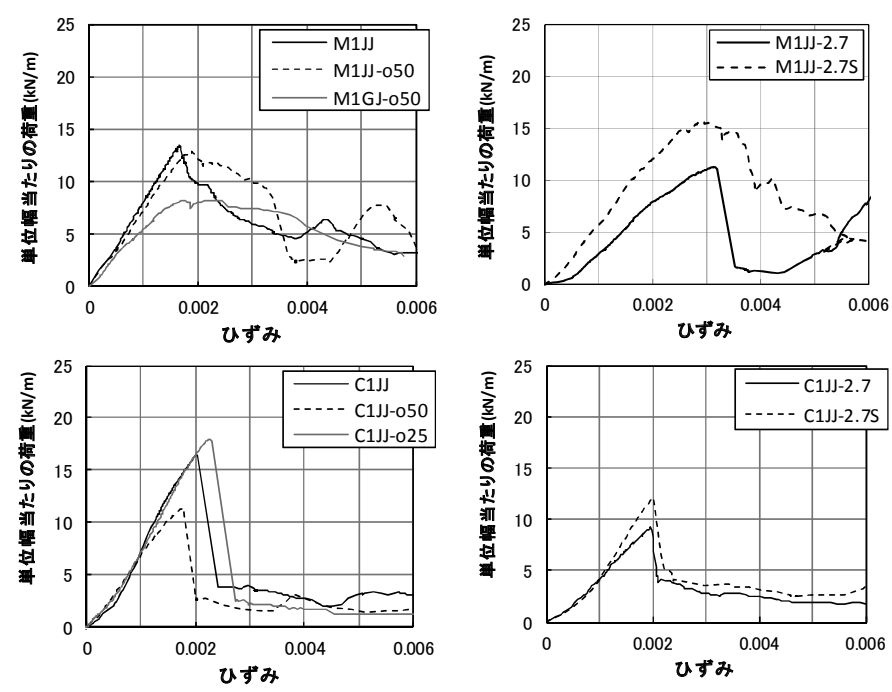

(d) 開口の有無・開口率の比較

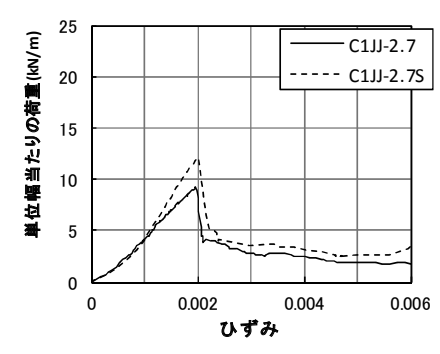

(e) 水平補剛材の有無の比較
検討も必要である。

（5）水平補剛材の有無の違いによる比較

図 7 (e) に水平補剛材の有無の違いによる単位幅当たりの荷重ひず み関係の比較を示す。M1JJ-2.7S、C1JJ-2.7S の損傷荷重は、それぞ れ M1JJ-2. 7、C1JJ-2.7 の約 1.3 倍となり、水平補剛材を取り付ける ことにより損傷荷重は大きくなり、天井懐が短くなるのと同様の効 果が確認できた。

（6）JIS クリップ・耐風圧クリップの違いによる比較

図 7 (f) にJIS クリップ、耐風圧クリップの違いによる単位幅当た りの荷重とひずみの関係の比較を示す。野縁方向圧縮においては、 M1JJ と M1JB は概ね同程度の損傷荷重であり、クリップの違いによ る差は見られなかった。

野縁受け方向圧縮では、C1JB（写真 3(b-1)）の損傷荷重は C1JJ の約 0.8 倍となり、耐風圧クリップの方が JIS クリップより小さか った。一方、下地配置の異なる $\mathrm{C} 1 \mathrm{~J}$ ”B (写真 $3(\mathrm{~b}-2)$ ) では、逆に C1JJ の 1.5 倍となり、下地配置の違いより損傷荷重は大きく変わる結果 となった。C1JB の損傷荷重が小さかった原因として、風圧クリップ を取り付けることにより接合部のすべりがなくなり、JIS クリップ
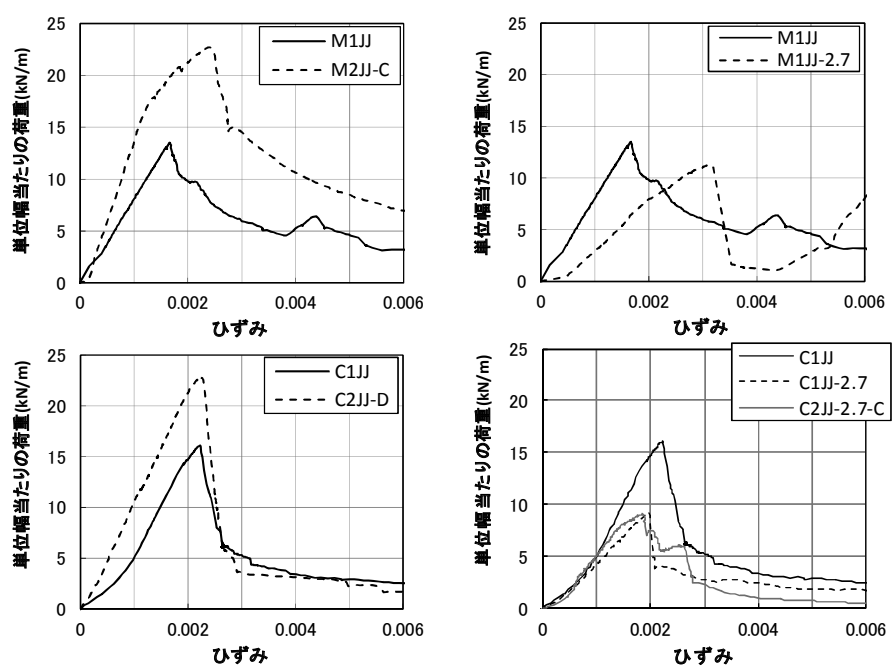

(b)ボード枚数の違いによる比較

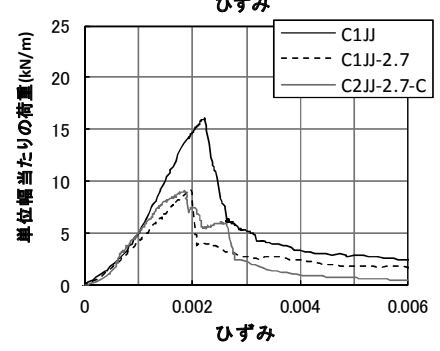

(c) 天井懷の違いによる比較
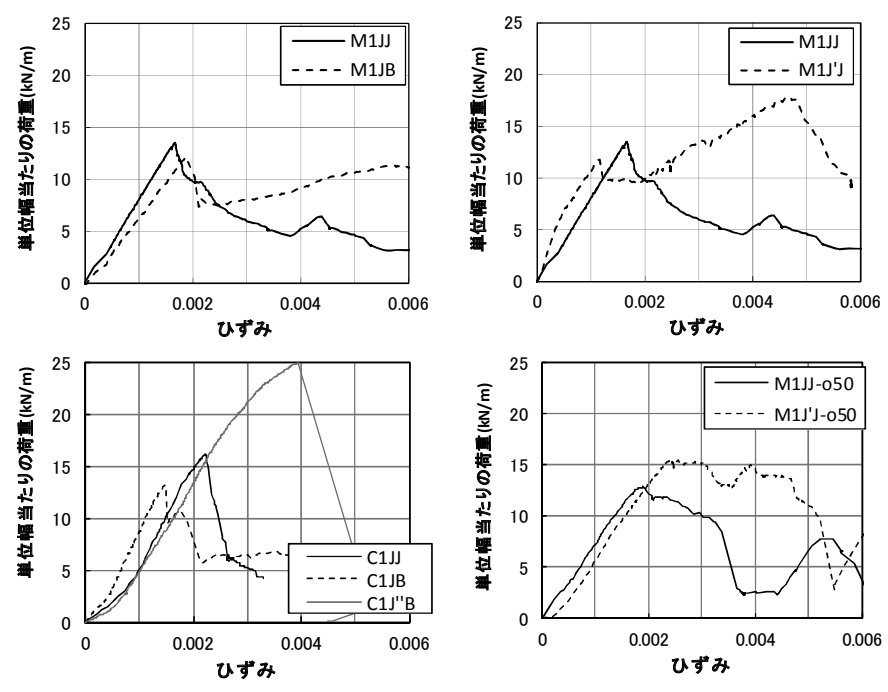

(f)クリップ・耐風圧クリップの比較

図 7 単位幅当たり（幅 $1 \mathrm{~m}$ 当たり）の荷重とひずみの関係 
に比べて端部でのボードの圧縮応力が増してしまうこと等が考えら れる。

（7）天井端部仕様の違いによる比較

図 $7(\mathrm{~g})$ に、天井端部仕様の違い（写真 $3(\mathrm{a}-1)$ 、 $(\mathrm{a}-2))$ による単 位幅当たりの荷重ひずみ関係の比較を示す。試験体 M1J'J、 M1J'J-050 はボード面と下地材端部が加力梁に当たった場合、試験 体M1JJ、M1JJ-050 はボード面のみが加力梁に当たった場合である。 損傷荷重は、M1J’ J は M1JJ の約 0.9 倍、M1J’ J-o50 は M1JJ-o50 の約 1.2 倍程度であった。M1J’ J では、加力梁に一部の下地材が当たり、 その下地材が座屈するとともに、下地材が接触していない部分のボ ードも座屈し耐力が低下した。その後他の下地材が加力梁に当たり、 再び荷重が上昇している。下地材端部が加力梁に当たる場合、耐力 の急激な劣化が避けられているが、当たり方や本数等の違いによっ ても挙動が異なると考えられ、再現性に乏しいと思われる。

（8）天井規模の違いによる比較

図 8 に天井規模の違いによる単位幅当たりの荷重ひずみ関係の比 較を示す。小規模試験体では、JIS クリップを使用したのに対し、 大規模試験体では耐風圧クリップを使用している。

図 8 (a) に示すように、野縁方向圧縮では、大規模試験体 (M2JB-L) の損傷荷重は約 $17 \mathrm{kN} / \mathrm{m}$ 、小規模試験体 (M $2 J J-C)$ では約 $23 \mathrm{kN} / \mathrm{m}$ で、 大規模試験体の損傷荷重は、小規模試験体の約 0.75 倍であった。 M2JB-L では損傷荷重後も目視で確認できる損傷は見られず、最終的 にひずみ 0.006 付近でボードのビス抜け（後述写真 5 (a)）が生じる まで損傷は確認できなかった。損傷荷重後に荷重が低下しているの は接合部のすべり等が原因として挙げられる。また、図 8(b)に示す ように、野縁受け方向圧縮では、大規模試験体 (C2JB-L) の損傷荷重 は、小規模試験体 (C2JJ-D) の損傷荷重の約 0.8 倍であり、何れも天 井規模が大きくなると損傷荷重は低下寸る傾向が見られた。

\section{2 吊りボルト軸力分布}

図 9 に小規模試験体の各試験体における吊りボルトに作用する損 傷荷重時の軸力分布の一例を示す(位置は図 1 参照)。縦軸の軸力は、 天井自重（約 38～67N）による引張り力が生じた状態で 0 としてい る。図中には計算から求めた弾性座屈荷重に達する軸力を一点鎖線 で併記した。試験体によりばらつきはあるものの、概観的には、端 部の吊りボルトに大きな圧縮軸力が作用し、例えば図 9 の囲み線で 示寸弾性座屈荷重を超えている吊りボルトでは大きなたわみが観察 された。また、中央部吊りボルト（X3）の軸力は 0、もしくは正值 寸なわち引張力が増す傾向が見られた。中央部と端部の間 (X2 と X4) の吊りボルトは端部のそれに比較して小さいが圧縮軸力が作用して いた。また、天井懷 $2.7 \mathrm{~m}$ の場合、端部が大きくなる傾向は天井懐 $1.5 \mathrm{~m}$ の場合と同じであるが、全体的に軸力は小さかった。

\section{3 試験体の破壊形態}

小規模試験体、大規模試験体の破壊形態の一例をそれぞれ写真 $4 、$ 写真 5 に示寸。破壞形態は、下地材と面材が一体となった天井面の 座屈、ボードの折れ、ボードからのビス抜け等が見られ、ほとんど の天井で端部が破壞した。野縁受け方向圧縮では、野縁受けに倒れ が生じた（写真 4(d))。開口有の試験体で、開口無より損傷荷重が 低下したC1JJ-050(写真 4 (e))では、開口の脇でボードが座屈した。 耐風圧クリップの $\mathrm{C} 1 \mathrm{JB}$ と $\mathrm{C} 1 \mathrm{~J}$ ” $\mathrm{B}$ の破壞形態の比較を写真 6 に示す。 上述、写真 $3(b-1) 、(b-2)$ で示したように、前者は野縁間隔が狭

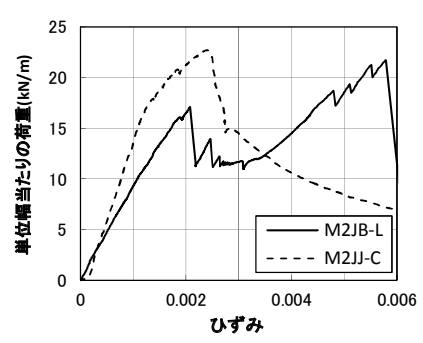

(a) 野縁方向加力

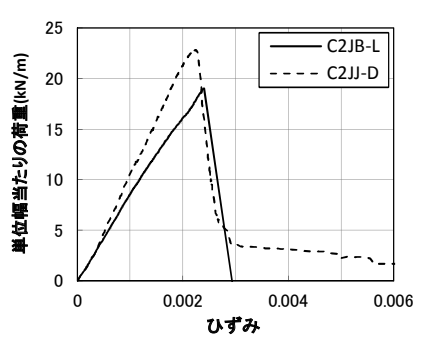

(b) 野縁受け方向加力
図 8 単位幅当たりの荷重とひずみの関係 (天井規模の違いによる比較)
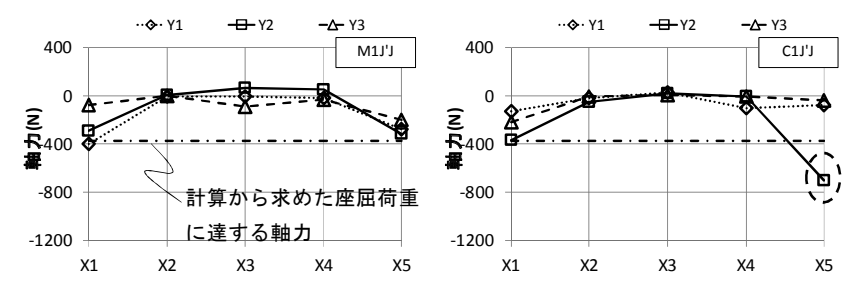

(a) 野縁方向圧縮 1 枚張り、天井懐 $1.5 \mathrm{~m}$ (b) 野縁受け方向圧縮 1 枚張り、天井懷 $1.5 \mathrm{~m}$
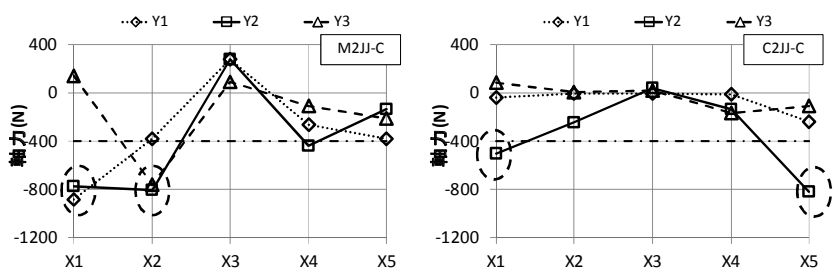

(c) 野縁方向圧縮 2 枚張り、天井懐 $1.5 \mathrm{~m}$

(d) 野縁受け方向圧縮 2 枚張り、天井懐 $1.5 \mathrm{~m}$
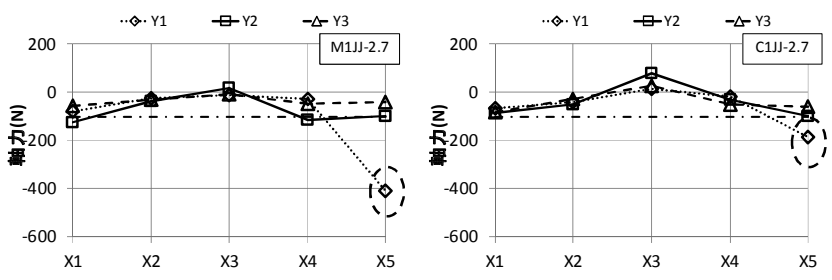

(e) 野縁方向圧縮 1 枚張り、天井懐 $2.7 \mathrm{~m} \quad$ (f) 野縁受け方向圧縮 1 枚張り、天井懐 $2.7 \mathrm{~m}$

図 9 吊りボルトの軸力分布（損傷荷重時）

い端部の隣の部分でボードが座屈している。一方、後者は天井端部 の野縁が均等に配置されているためか、野縁間でボードは座屈せず、 最終的には写真 6 (b) に示すように天井端部のボードからのビス抜 けにより損傷している。耐風圧クリップを用いた場合、両者の損傷 荷重には大きな差があることから、天井端部の仕様が損傷荷重に与 える影響は大きく、特に配慮が必要であると考えられる。

\section{4 損傷荷重に相当する天井長さ}

実験結果をもとに、実現可能な規模を把握するため、損傷荷重 $P_{d}(\mathrm{kN} / \mathrm{m})$ に相当する天井長さ $L_{d}(\mathrm{~m})$ を次式で試算する。

$$
L_{d}=P_{d} /(k \times w)
$$

ここで、 $k$ は設計震度、 $w\left(\mathrm{kN} / \mathrm{m}^{2}\right)$ は単位面積重量である。 $k=1$ とし て求めた $L_{d}$ を前出表 2 の右端の欄に示すとともに、図 10 に設計震 度 $k$ と天井長さ $L_{d}$ の関係を例示する。設計震度は動的実験の結果や 各種の安全率等を考慮して決められるもので本稿の範囲では断定で きないが、例えば $k=2$ とすると、図 10 (a) の M $1 J J$ の場合に $L_{d}$ は約 $75 \mathrm{~m}$ となる。不可避的な隙間による衝撃力等を考慮して大きめに $k=5$ とすると、およそ $25 \mathrm{~m} \sim 40 \mathrm{~m}$ となる。なお、天井の耐震性を確保する 

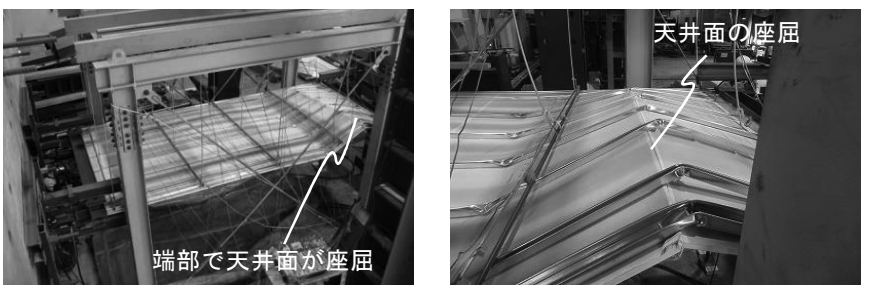

(a) M1 J' J

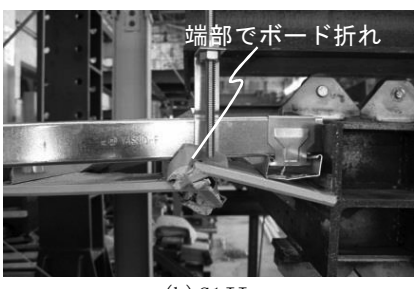

(b) C1JJ

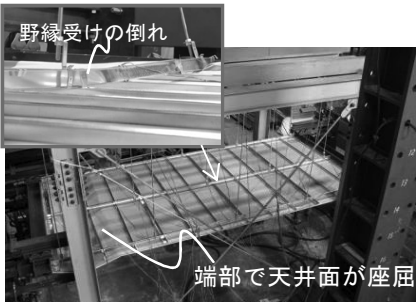

(d) C2JJ-C

写真 4 天井の破壊形態（小規模試験体）

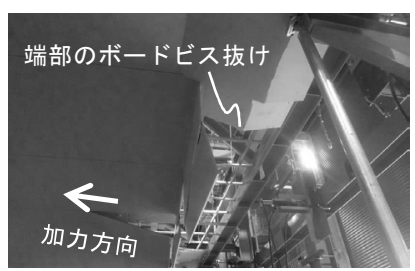

(a) M2JB-L

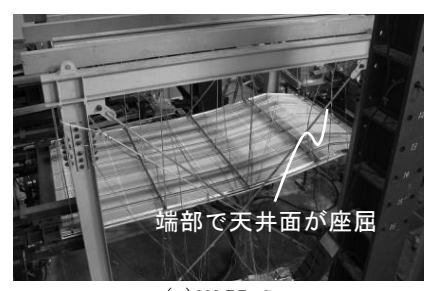

(c) $\mathrm{M} 2 \mathrm{JJ}-\mathrm{C}$

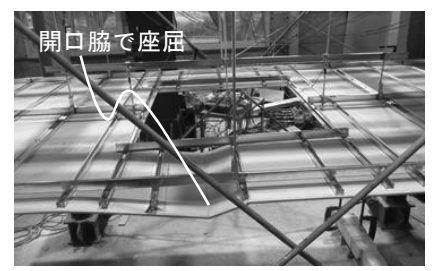

(e) $\mathrm{C} 1 \mathrm{JJ}-\mathrm{o} 50$

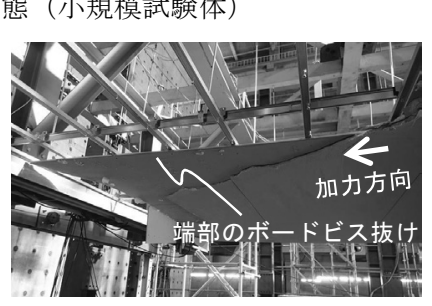

(b) C2 JB-L
写真 5 天井の破壊形態（大規模試験体）

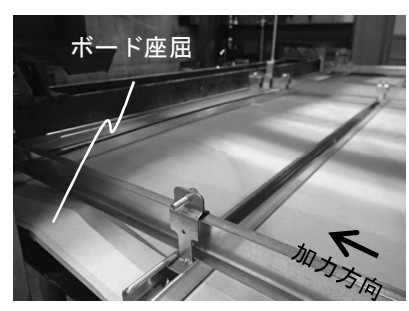

(a) $\mathrm{C} 1 \mathrm{JB}$

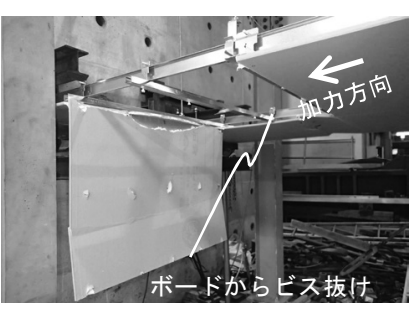

(b) $\mathrm{C} 1 \mathrm{~J}$ "B
写真 $6 \mathrm{C} 1 \mathrm{JB}$ と $\mathrm{C} 1 \mathrm{~J}$ ”B の破壊形態の比較

上では、天井周囲の壁等には天井と同等以上の耐力をもたせる必要 があることに留意する。また、天井長さによる耐力低下についても 実規模での実験は困難であることから、低減率等を用いて適切に評 価することが必要である。

\section{4. まとめ}

クリアランスを設けない天井の耐震性を検討寸る上で必要となる 天井の面内剛性、耐力、および破壊性状を静的面内圧縮実験により 把握した。以下に、得られた結果をまとめる。

\section{損傷荷重}

・圧縮方向で比較すると、1 枚張りは野縁受け方向圧縮が、野縁方 向圧縮の約 1.2 倍、2 枚張りではほとんど差は見られなかった。 ・ボード 2 枚張りは、 1 枚張りの 1.4 倍〜 1.9 倍であった。

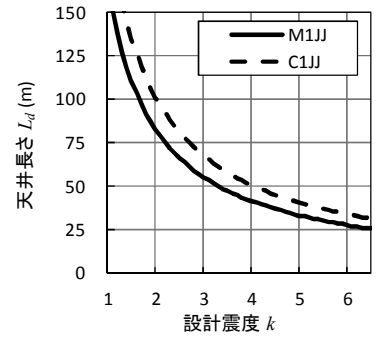

(a) 圧縮方向の違いによる比較

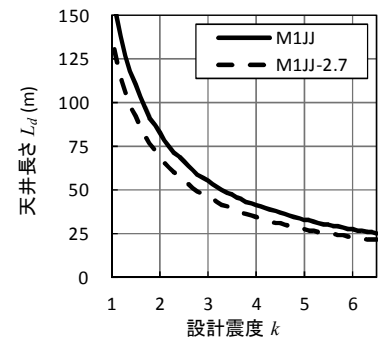

(b) 天井懐の違いによる比較
図 10 設計震度と天井長さの関係

・天井懐が長いほど低下寸る傾向が見られた。

・開口率 25\%では開口無と同程度、開口率 $50 \%$ では野縁方向圧縮で開 口無と同程度、野縁受け方向圧縮では開口無の約 0.7 倍であった。 ・水平補剛材を取り付けた場合は、水平補剛材がない場合の約 1.3 倍であった。

・耐風圧クリップを取り付けた場合、JIS クリップに比較して、野 縁方向圧縮では同程度、野縁受け方向圧縮では約 1.5 倍であった。 ただし、天井端部の下地配置によっては大きく低下した。

・天井規模が大きくなると低下寸る傾向が見られた。

\section{吊りボルト軸力分布}

・面内圧縮時の吊りボルトの軸力は、端部の吊りボルトに大きな圧 縮力が生じ、中央部になるにしたがい小さくなる傾向が見られた。

\section{設計震度と天井長さ}

・実験結果から損傷荷重に相当する天井長さを示した。

\section{天井の破壊形態}

・天井の破壊形態は、下地材と面材が一体となった天井面の座屈、 ボードの折れ、ボードからのビス抜け等が見られた。ほとんどの 試験体で端部が破壊した。

今後の課題として、開口の位置が耐力に与える影響、天井長さの 違いによる耐力低減率の検討、同一仕椂による試験結果のばらつき の検討等が挙げられる。

【謝辞】

本研究は平成 25 年度建築基準整備促進事業として実施したもの に一部追加してまとめたものである。当該事業では清家剛准教授 (東 京大学)、元結正次郎教授 (東京工業大学) をはじめ、委員・協力委 員の方々から有益なご助言を頂いた。また一部の実験にはBRIC 勉強 会（筑波建築研究機関協議会）の協力を得た。ここに記して謝意を 表す。

\section{【参考文献】}

1) 特定天井及び特定天井の構造耐力上安全な構造方法等を定める件（平成 25 年国土交通省告示第 771 号)、ほか、官報号外第 170 号、2013.8.5

2) 中西敦士、元結正次郎、國崎洋、船積宏章 : 野縁方向における天井面圧縮 時の挙動に関する検討（鋼製下地在来工法天井における天井面の安定性に 関する研究その 1 〜その 3 )、日本建築学会大会学術講演梗概集、pp. 881-886、 2012. 9

3) 日本建築学会非構造材の安全性評価及び落下事故防止に関する特別調査委 員会 : 天井等の非構造部材の落下事故防止ガイドライン、2013 年 3 月版

4) 石原直、稲井慎介、森田泰弘、渡壁守正、脇山善夫、喜々津仁密 : 周囲の 壁等に慣性力を負担させる水平な在来工法天井の耐震性に関する実験的研 究 その 1〜その 3、日本建築学会大会学術講演梗概集、pp. 977-982、2014.9

5) 石原直、稲井慎介、森田泰弘、渡壁守正、脇山善夫、喜々津仁密：鋼製下 地吊り天井の天井面の曲げに関する力学特性、日本建築学会技術報告集、 第 21 巻第 47 号、pp. $45-48 、 2015.2$

[2014 年 10 月 15 日原稿受理 2014 年 11 月 25 日採用決定］ 